\title{
Penerapan Model Pembelajaran Cooperative Learning untuk Meningkatkan Motivasi Belajar pada Mata Kuliah Kapita Selekta Pendidikan Mahasiswa FKIP UNISRI
}

\author{
Sugiaryo $^{1} \&$ Sutoyo $^{2}$ \\ Pendidikan Pancasila dan Kewarganegaraan, \\ Universitas Slamet Riyadi Surakarta \\ sugiaryo.unisri@gmail.com; sutoyo@gmail.com
}

\begin{abstract}
Learning is a daily activity for students. there are also learning activities that do not include lecturer designs, because of the students' own desires. There are several motivational theories, among others: encouragement theory, intensive theory, achievement motivation theory, competency motivation theory and motivation needs theory. cooperative learning system or cooperative learning is a teaching system that provides opportunities for fellow students to work together on structured tasks. Cooperative learning is known as group learning. This research is a Classroom Action Research (CAR) which can also be called development research. The study was conducted in 2 cycles, by applying methods in cooperative learning. Based on the discussion that has been done in the previous chapter in general it can be concluded that the application of STAD type cooperative learning methods can increase student motivation in the Capita Selekta Education Course. This was evidenced by the average student motivation in the high category in both Cycle I and Cycle II with a percentage of 56.25 and $62.50 \%$. With an increase in student motivation significantly also affect the results of learning evaluations with a complete score category $>75$.
\end{abstract} research

Keyword: cooperative learning, learning motivation, classroom action

\section{PENDAHULUAN}

Belajar merupakan kegiatan sehari-hari bagi mahasiswa. Kegiatan belajar tersebut ada yang dilakukan di kampus, di rumah maupun di tempat lain seperti di laboratorium dan di perpustakaan. Ditinjau dari segi dosen, kegiatan belajar ada yang tergolong dirancang oleh dosen dalam desain instruksional. Kegiatan belajar yang termasuk rancangan dosen antara lain mahasiswa mengerjakan tugas-tugas belajar di kampus, di laboratorium, maupun di perpustakaan. Di samping itu, ada juga kegiatan belajar yang tidak termasuk rancangan dosen, karena keinginan mahasiswa sendiri. Pengetahuan tentang belajar karena ditugasi dan belajar karena motivasi diri penting bagi dosen. 
Motivasi merupakan kondisi psikologis yang memberikan kontribusi besar terhadap seseorang untuk melakukan sesuatu guna mencapai tujuan. Dengan demikian, motivasi belajar menjadi suatu hal yang penting untuk diperhatikan agar tercapainya kualitas pembelajaran, baik proses pembelajaran maupun hasil belajar mahasiswa. Selain dari dalam diri mahasiswa, motivasi belajar ini dapat ditumbuhkan oleh faktor luar, seperti lingkungan belajar baik fisik maupun psikologis.

Usaha peningkatan motivasi belajar mahasiswa terkait erat dengan pelaksanaan pembelajaran. Pembelajaran sendiri merupakan suatu proses yang sangat kompleks dan melibatkan berbagai aspek yang saling berkaitan, seperti pengelola pembelajaran (dosen), subjek belajar (mahasiswa), lingkungan belajar (media, model, metode, sarana prasarana dan lain-lain) serta hasil belajar. Metode pembelajaran merupakan cara yang digunakan dosen untuk mengimplementasikan rencana yang sudah disusun dalam bentuk kegiatan nyata dan praktis untuk mencapai tujuan pembelajaran. Metode ini termasuk salah satu komponen dalam pembelajaran yang berada di bawah kontrol dosen, artinya bahwa dosen mempunyai wewenang penuh untuk memilih metode yang tepat agar tercapai tujuan pembelajaran yang diinginkan. Pemilihan metode ini sangat berpengaruh terhadap keberhasilan pembelajaran karena metode yang kurang tepat akan menjadikan pembelajaran seperti sebuah pemaksaan, monoton, dan materi tidak tersampaikan dengan baik.

Suasana pembelajaran sudah diusahakan sedemikian rupa untuk mengkondisikan keterlibatan mahasiswa secara aktif dalam pembelajaran. Namun kenyataannya, hanya mahasiswa tertentu saja $(<30 \%)$ yang terlibat secara aktif, seperti menanggapi apa yang sudah disampaikan dosen, bertanya dengan kritis serta bersegera menyelesaikan tugas yang diberikan. Hal ini mengisyaratkan masih rendahnya motivasi belajar mahasiswa. Oleh karena itu, diperlukan upaya untuk meningkatkan motivasi belajar mahasiswa. Salah satu hal yang dapat dilakukan adalah dengan menerapkan model pembelajaran yang menuntut partisipasi aktif mahasiswa. Salah satu model pembelajaran yang dapat diterapkan adalah pembelajaran kooperatif. Model ini dikembangkan untuk mencapai minimal 3 tujuan penting dalam pembelajaran, yaitu hasil belajar akademis, toleransi dan penerimaan terhadap keanekarangaman serta pengembangan keterampilan sosial (Arends, 2008).

Lebih jauh, Zakaria (2007) menyatakan bahwa pembelajaran kooperatif menciptakan kesempatan yang luas bagi mahasiswa agar terlibat dalam penyelesaian masalah dengan bekerjasama dalam suatu kelompok. Pembelajaran kooperatif memberikan peluang untuk saling ketergantungan positif di antara mahasiswa dalam mencapai tujuan pembelajaran. Setiap mahasiswa mempunyai kesempatan yang sama untuk sukses. Aktivitas belajar berpusat pada mahasiswa dalam bentuk diskusi, mengerjakan tugas bersama, saling membantu dan saling mendukung dalam memecahkan masalah. Melalui interaksi belajar yang efektif mahasiswa lebih termotivasi, percaya diri, mampu menggunakan strategi berpikir tingkat tinggi, serta mampu membangun hubungan interpersonal. Metode 
pembelajaran kooperatif memungkinkan semua mahasiswa dapat menguasai materi pada tingkat penguasaan yang relatif sama atau sejajar.

Dalam setiap proses pembelajaran, terdapat mahasiswa yang memenuhi standar kriteria yang diinginkan, namun ada pula ada mahasiswa yang belum mampu mencapai standar minimal pencapaian tujuan yang ditetapkan oleh dosen. Dari hasil pengamatan, yang dilakukan di Progdi PPKn FKIP Unisri, ditemukan adanya mahasiswa yang tampak segan belajar, terutama pada mata kuliah Kapita Selekta Pendidikan. Hal ini ditunjukkan dari kurangnya perhatian mahasiswa dalam mengikuti perkuliahan mata kuliah Kapita Selekta Pendidikan, rendahnya keingintahuan mahasiswa terhadap mata kuliah Kapita Selekta Pendidikan. Hal ini menunjukkan rendahnya motivasi belajar mahasiswa dalam mata kuliah Kapita Selekta Pendidikan. Kondisi ini terjadi karena model pembelajaran yang diterapkan oleh dosen masih bersifat konvensional, yakni masih bertumpu pada dosen, mahasiswa kurang aktif di dilibatkan dalam proses pembelajaran. Untuk mengatasi kondisi tersebut, perlu penerapan model pembelajaran yang berorientasi pada keaktifan belajar mahasiswa. Model pembelajaran yang dirasakan efektif untuk mengatasi kondisi tersebut adalah model pembelajaran cooperative learning.

\section{Rumusan Masalah}

Bertolak dari latar belakang masalah tersebut, maka dalam penelitian ini diajukan rumusan masalah penelitian sebagai berikut:

"Apakah penerapan model pembelajaran cooperative learning dapat meningkatkan motivasi belajar pada mata kuliah Kapita Selekta Pendidikan pada mahasiswa semester IV Program Studi PPKn FKIP Unisri?"

\section{TINJAUAN PUSTAKA}

\subsection{Teori Motivasi}

Soekamto (1992) mengemukakan bahwa terdapat beberapa teori motivasi antara lain: teori dorongan, teori intensif, teori motivasi berprestasi, teori motivasi kompetensi dan teori motivasi kebutuhan Maslow. Teori dorongan mengatakan bahwa tingkah laku seseorang didorong kearah suatu tujuan tertentu karena adanya suatu kebutuhan. Kebutuhan ini menyebabkan adanya dorongan internal yang mendorong seseorang untuk melaksanakan sesuatu ke arah terciptanya atau tercapainya suatu tujuan. Tercapainya suatu tujuan tersebut selanjutnya akan menyebabkan intensitas dorongan.

Teori intensif mengatakan bahwa adanya suatu karakteristik tertentu yang dapat menyebabkan terjadinya tingkah laku ke arah tercapainya tujuan. Tujuan yang menyebabkan terjadinya perubahan tingkah laku tersebut dinamakan intensif.

Teori motivasi berprestasi mempunyai motivasi untuk bekerja keras karena adanya kebutuhan. Motivasi ini mempunyai fungsi tiga variabel, yaitu harapan untuk melakukan tugas dengan berhasil, persepsi tentang nilai tugas dan 
kebutuhan untuk berprestasi. Kebutuhan untuk berprestasi ini bersifat instrinsik dan relatif stabil. Dengan motivasi ini guru dapat mengetahui sejauhmana kebutuhan siswa untuk berprestasi. Dengan demikian guru akan dapat memanipulasi motivasi atau memberikan tugas-tugas yang sesuai untuk masingmasing siswa.

Teori motivasi kompetensi berpendapat bahwa setiap manusia mempunyai keinginan untuk mewujudkan kompetensi dengan menaklukkan lingkungannya, terutama motivasi belajar pada siswa yang bersifat internal. Guru dapat meningkatkan motivasi kompetensi siswa dengan cara menerapkan pendekatan internal, sehingga kinerja siswa berubah dan siswa dapat mengontrol prestasinya. Selain itu juga dapat dilakukan dengan jalan evaluasi diri terhadap tugas-tugas yang diberikan kepada siswa.

Teori motivasi kebutuhan Maslow dapat dikelompokkan menjadi dua, yaitu kebutuhan defisiensi dan kebutuhan pengembangan. Defisiensi adalah kebutuhan-kebutuhan fisiologis, keamanan dicintai serta diakui dalam kelompoknya dan harga diri/prestasi. Sedangkan kebutuhan pengembangan mencakup kebutuhan aktualisasi diri, keinginan untuk mengetahui dan memahami serta kebutuhan estetis. Teori motivasi kebutuhan Maslow dapat digambarkan sebagai berikut:

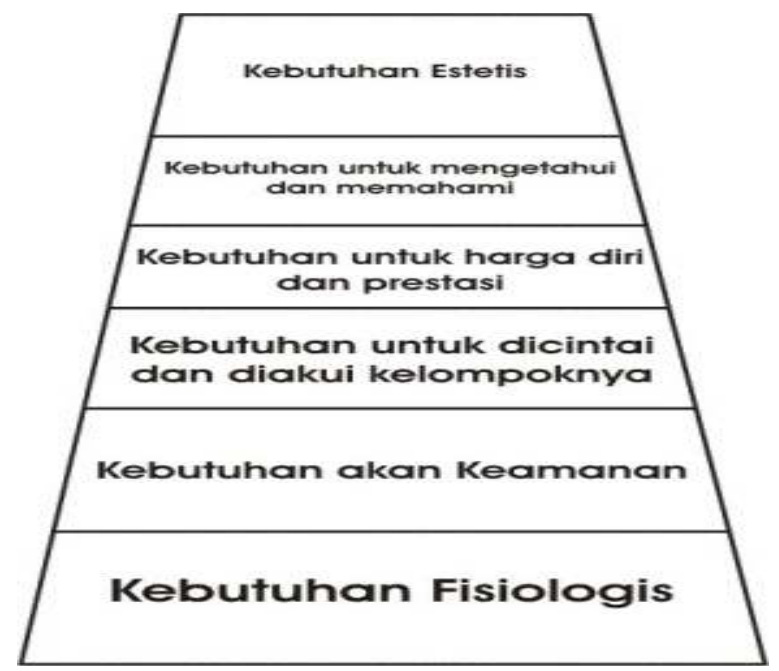

Gambar 1. Teori Motivasi Kebutuhan Maslow

Kebutuhan fisiologis adalah kebutuhan akan minum, makan, pakaian dan tempat tinggal, termasuk di dalamnya kebutuhan biologis seperti seks. Kebutuhan seks ditempatkan sebagai paling dasar, oleh karena itu harus mendapatkan prioritas utama untuk dipenuhi.

Kebutuhan rasa aman meliputi rasa aman secara fisik maupun rasa aman secara psikis. Rasa aman secara fisik misalnya terhindar dari gangguan kriminalitas, teror, gangguan dari binatang buas, gangguan dari orang lain dan gangguan dari bangunan dan tempat yang tidak aman. Rasa aman secara psikis 
misalnya tidak banyak kena marah, tidak banyak kena damprat, tidak banyak diejek, tidak direndahkan harga dirinya maupun tidak dipindahtempatkan secara sembarang.

Kebutuhan dicintai dan diakui dalam kelompoknya adalah erat kaitannya dengan kebutuhan sosial. Kebutuhan sosial ini erat kaitannya dengan kedudukan manusia sebagai makhluk sosial. Sebagai makhluk sosial, ia butuh agar dianggap sebagai warga komunitas sosialnya. Kebutuhan sosial ini mengandung arti bahwa ia harus diterima oleh orang lain. Kebutuhan sosial ini sangat penting artinya bagi siswa yang sedang belajar. Oleh karena itu, siswa senantiasa harus dapat diterima dengan baik oleh kelompok siswa yang lain.

Kebutuhan harga diri (prestasi) adalah kelanjutan dari kebutuhan sosial. Ia ingin prestise dan berprestasi. Oleh karena itu, siswa membutuhkan kepercayaan tanggung jawab yang menantang, sehingga dapat melakukan aktivitas. Jika kebutuhan ini diterapkan dalam pembelajaran, siswa haruslah diberikan banyak tugas-tugas yang menantang, tetapi dalam kerangkan kemampuan dirinya. Dengan tugas-tugas yang menantang ini siswa termotivasi untuk belajar lebih giat.

Kebutuhan aktualisasi diri adalah kebutuhan untuk membuktikan dirinya dan menunjukkan dirinya kepada orang lain. Oleh karena itulah pada tahapan pemenuhan kebutuhan ini, ia mengembangkan semaksimal mungkin potensi yang dimiliki, apapun potensinya. Pemenuhan kebutuhan aktualisasi diri ini membutuhkan suasana yang kondusif dari lingkungan, sehingga seseorang dapat dengan bebas mengaktualisasikan dirinya. Pada diri seorang siswa, ekspresi dari seluruh totalitas tercurah dengan baik manakala terdapat suasana pembelajaran yang di-setting secara baik, baik di kelas maupun di luar kelas. Dengan terpenuhinya kebutuhan aktualisasi diri ini, akan memotivasi seseorang untuk mengembangkan keingintahuan dan memahami kebutuhan estetis.

Kebutuhan estetis atau kebutuhan keindahan ini memang tidak menjadikan penyebab timbulnya atau meningkatnya motivasi seseorang. Akan tetapi jika diperhatikan, dapat menumbuhkan motivasi seseorang. Karena itu kebutuhan estetis merupakan prasyarat bagi munculnya faktor motivasi.

\subsection{Jenis Jenis Motivasi}

Motivasi dapat dibedakan atas motivasi intrinsik dan ekstrinsik (Imron, 1996). Motivasi intrinsik adalah motivasi yang berasal dari dalam individu. Sedangkan motivasi ekstrinsik adalah motivasi yang berasal dari luar individu.

Menurut Rahmat, motivasi dapat dibedakan menjadi dua jenis, yaitu motivasi primer dan motivasi sekunder. Motivasi primer adalah motivasi yang didasarkan pada motif-motif dasar. Motif-motif dasar tersebut umumnya beraal dari segi biologis atau jasmani manusia. Moivasi sekunder adalah motivasi yang dipelajari. Sebagai ilustrasi, orang yang lapar akan tertarik pada makanan tanpa belajar (Rakhmat, 1991). Untuk memperoleh makanan tersebut orang harus bekerja terlebih dahulu. Agar dapat bekerja dengan baik, orang harus belajar bekerja. Bekerja dengan baik merupakan motivasi sekunder. 
Menurut Suryabrata (2011) menyebutkan bahwa motivasi sekunder disebut sebagai motivasi sosial. Menurutnya, motivasi sosial memegang peranan penting bagi perilaku manusia. Perilaku manusia terpengaruh oleh tiga komponen penting yaitu afektif, kognitif dan konatif. Komponen afektif adalah aspek emosional, yang terdiri dari motif sosial, sikap dan emosi. Komponen kognitif adalah terkait dengan kemauan dan kebiasaan bertindak.

Ahli lain, Gunarsa menggolongkan motivasi sekunder menjadi: (1). Kebutuhan organisme, seperti motif ingin tahu, memperoleh kecakapan, memperoleh prestasi; dan (2). Motif-motif sosial, seperti kasih sayang, kekuasaan dan kekebasan. Perilaku motivasi sekunder terpengaruh oleh adanya sikap. Sikap adalah suatu motif yang dipelajari. Ciri-ciri sikap yakni, merupakan: (1). kecenderungan berpikir, merasa, kemudian bertindak, (2). Memiliki daya dorong bertindak; (3). Relatif bersifat tetap; (4). Kecenderungan melakukan penilaian; dan (5). Dapat timbul dari pengalaman, dapat dipelajari atau berubah (Gunarsa, 1990).

\subsection{Hakekat Motivasi Belajar}

Motivasi belajar merupakan salah satu faktor yang turut menentukan keefektifan dalam pembelajaran. Seorang peserta didik akan belajar dengan baik apabila ada faktor pendorongnya yaitu motivasi belajar. Peserta didik akan belajar dengan sungguh-sungguh jika memiliki motivasi belajar yang tinggi.

Menurut Uno (2011), motivasi belajar adalah dorongan internal dan eksternal pada siswa yang sedang belajar untuk mengadakan tingkah laku, pada umumnya dengan beberapa indikator atau unsur-unsur yang mendukung. Indikator-indikator tersebut, antara lain: adanya hasrat dan keinginan berhasil, dorongan dan kebutuhan dalam belajar, harapan dan cita-cita masa depan, penghargaan dalam belajar, dan lingkungan belajar yang kondusif.

Selain itu, Winkel (2004) menyebutkan motivasi belajar adalah keseluruhan daya penggerak psikis didalam siswa yang menimbulkan kegiatan belajar itu demi mencapai suatu tujuan. Sejalan dengan pendapat di atas, Sardiman (2007), menjelaskan motivasi belajar adalah seluruh daya penggerak didalam diri siswayang menimbulkan kegiatan belajar sehingga tujuan yang dikehendaki oleh subjek belajar itu dapat dicapai.

\subsection{Motivasi dalam Belajar}

Menurut Winkel, dalam membicarakan soal motivasi belajar, terdapat dua sudut pandang. Pertama, motivasi intrinsik yaitu motivasi yang terbentukkarena kesadaran diri atas pemahaman betapa pentingnya belajar untukmengembangkan dirinya dan bekal untuk menjalani kehidupan. Kedua, motivasi ekstrinsik yaitu motivasi yang berupa rangsangan dari orang lain, ataulingkungan sekitarnya yang dapat memengaruhi psikologis orang yangbersangkutan.

Baik motivasi intrinsik maupun motivasi ekstrinsik sama-sama berfungsi sebagai pendorong, penggerak, dan penyeleksi perbuatan. Ketiganya menyatu dalam sikap terimplikasi dalam perbuatan. Karena itulah baik dorongan, 
penggerak maupun penyeleksi merupakan kata kunci dari motivasi dalam setiap perbuatan dalam belajar. Sejalan dengan hal tersebut, Hamalik (2011) menyebutkan beberapa fungsi dari motivasi antara lain:

1) Mendorong timbulnya kelakuan/ suatu perbuatan.

2) Motivasi berfungsi sebagai pengarah, artinya mengarah pada perbuatan ke pencapaian tujuan yang diinginkan.

3) Motivasi berfungsi sebagai penggerak, artinya sebagai motor penggerak dalam kegiatan belajar.

Dalam meningkatkan motivasi belajar tentunya tidak lepas dari faktorfaktor yang dapat memompa motivasi belajar dari dalam diri mahasiswa. Menurut Dimyati dan Mudjiono (2009) berikut faktor yangmempengaruhi motivasi belajar:

1) Cita-cita atau aspirasi mahasiswa

Cita-cita mahasiswa untuk menjadi seseorangyang suskes akan memperkuat semangat belajar danmengarahkan pelaku belajar. Cita-cita akan memperkuatmotivasi belajar intrinsik maupun ektrinsik sebab tercapainyasuatu cita-cita akan mewujudkan aktualisasi diri.

2) Kemampuan belajar

Kemampuanbelajar meliputi beberapa aspek psikis yang terdapat dalam dirisiswa.Misalnya pengamatan, perhatian, ingatan, daya pikir danfantasi. Didalam kemampuan belajar, perkembangan berfikir siswa menjadi ukuran. Mahasiswa yangtaraf perkembangan berpikirnya konkrit (nyata) tidak samadengan mahasiswa yang berpikir secaraoperasional(berdasarkan pengamatan yang dikaitkan dengan kemampuandaya nalarnya). Jadi mahasiswa yang mempunyai kemampuanbelajar tinggi, biasanya lebih termotivasi dalam belajar, karenamahasiswa seperti itulebih sering memperoleh sukses olehkarena kesuksesan memperkuat motivasinya.

3) Kondisi jasmani dan rohani mahasiswa

Kondisi mahasiswa yang mempengaruhi motivasibelajar berkaitan dengan kondisi fisik dan kondisipsikologis, tetapi biasanya dosenlebih cepat melihat kondisifisik, karena lebih jelas menunjukkan gejalanya dari padakondisi psikologis. Misalnya mahasiswa yang kelihatan lesu,mengantuk mungkin juga karena malam harinya bergadang ataujuga sakit.

4) Kondisi lingkungan kelas

Lingkungan mahasiswa sebagaimanajuga lingkungan individu pada umumnya ada tiga yaitulingkungan keluarga, kampus dan masyarakat. Jadi unsurunsuryang mendukung atau menghambat kondisi lingkungan berasaldari ketiga lingkungan tersebut. Hal ini dapat dilakukanmisalnya dengan cara bersama dosen berusaha mengelola kelas,menciptakan suasana belajar yang menyenangkan, menampilkandiri secara menarik dalam rangka membantu mahasiswatermotivasi dalam belajar.

5) Unsur-unsur dinamis belajar

Unsur-unsur dinamis dalam belajar adalah unsur-unsur yangkeberadaannya dalam proses belajar yang tidak stabil, kadanglemahdan bahkan hilang sama sekali. 
6) Upaya dosendalam mengajar mahasiswa

Upaya dosen dalam mengajar mahasiswa adalah usaha dosen dalammempersiapkan diri untuk membelajarkan mahasiswa mulai daripenguasaan materi, cara menyampaikannya, menarik perhatianmahasiswa dan mengevaluasi hasil belajar mahasiswa. Bilaupaya dosen hanya sekedar mengajar, artinya keberhasilan dosenyang menjadi titik tolak, besar kemungkinan mahasiswa tidaktertarik untuk belajar sehingga motivasi belajar mahasiswamenjadi melemah atau hilang.

\subsection{Tinjauan Tentang Cooperative Learning}

Menurut Sugandi (2000) sistem pembelajaran gotong royong atau cooperative learning merupakan sistempengajaran yang memberi kesempatan kepada sesamasiswa untuk bekerja sama dengan dalam tugas-tugas yang terstruktur. Pembelajaran kooperatif dikenal denganpembelajaran secara berkelompok. Tetapi belajar kooperatif lebih dari sekedar belajarkelompok atau kerja kelompok karena dalam belajar kooperatif ada struktur dorongan atautugas yang bersifat kooperatif sehingga memungkinkan terjadinya interaksi secara terbukadan hubungan yang bersifat interdepedensi efektif diantara anggota kelompok. Hubungan kerja seperti itu memungkinkan timbulnya persepsi yang positif tentang apayang dapat dilakukan siswa untuk mencapai keberhasilan belajar berdasarkan kemampuandirinya secara individu dan andil dari anggota kelompok lain selama belajar bersama dalamkelompok.

Menurut Jadmiko (2004), pembelajaran kooperatif adalah suatu sistem yang didalamnya terdapat elemen-elemen yang saling terkait. Adabeberapa elemen yang merupakan ketentuan pokok dalam pembelajaran kooperatif,yaitu: 1) positive interdependence, 2) face to face interaction, 3) individual accountability, dan 4) use of collarative/ social skill.

Dalam pembelajaran kooperatifsiswa belajar dalam kelompokkelompokkecil yang memiliki tingkat kemampuanberbeda. Dalam menyelesaikan tugas kelompok, setiap anggota saling bekerjasama dan membantu untuk memahami suatu bahan pembelajaran. Belajar belumselesai jika salah satu teman dalam kelompok belum menguasai bahanpembelajaran (Jatmiko, 2004). Sebagaimana pembelajaran inovatif padaumumnya pembelajaran kooperatifbertujuan untuk meningkatkan prestasibelajar anak. Siswa akan belajar lebihefisien dalam proses pembelajaran kelompok (Te-Yi Chan, dkk, 2008). Attle dan Baker (2007) jugamenemukan bahwa melalui pembelajaran kooperatif siswa dapat memaksimalkan perkembangan profesional mereka. Selainitu, pembelajaran kooperatif masih memilikikeunggulan lain, yaitu banyak atribut soft skills dapat dilatihkan, seperti kerjasama (teamwork), keterampilan berkomunikasi, pengambilan keputusan, disiplin,manajemen waktu, kejujuran.

Pembelajaran kooperatif telah dikembangkan secara intensif melalui berbagai penelitian. Model pembelajaran kooperatif dikembangkan denganberpijak pada beberapa pendekatan yang diasumsikan mampu meningkatkan proses dan hasil belajar mahasiswa. Pendekatan yang dimaksud 
adalah belajaraktif, konstruktivistik, dan kooperatif.Menurut Arends, terdapat empat pendekatan pokok dalam model pembelajaran kooperatif, yaitu STAD (Students Teams Achievement Divisions), Jigsaw, serta GI (Group Investigation) serta pendekatan struktural. Ketiga pendekatan awal dikembangkan lebih lanjut menjadi model dan metode pembelajaran kooperatif STAD, Jigsaw dan GI dengan sintaks-sintaks tertentu. Adapun pendekatan struktural dikembangkan menjadi metode thinkpairshare dan numbered heads together.

Model pembelajaran kooperatif dikembangkan, setidaknya untuk tiga tujuan pembelajaran sesuai yang dikemukakan oleh Ibrahim, dkk (2000) sebagai berikut:

1) Meningkatkan kinerja siswa dalam tugas-tugas akademik.

2) Mengajarkan untuk saling menghargai satu sama lain.

3) Mengajarkan keterampilan kerjasama dan kolaborasi.

Agus Suprijono mengatakan bahwa tidak semua belajar kelompok bisa dianggap pembelajaran kooperatif (Suprijono, 2009). Untuk mencapai hasil yang maksimal, dalam model pembelajaran kooperatif harus diterapkansebagai berikut.

1) Positive interdependence (saling ketergantungan positif). Unsur ini menunjukkan bahwa dalam pembelajaran kooperatif ada dua pertanggungjawaban kelompok. Pertama, mempelajari bahan yang ditugaskan kepada kelompok. Kedua, menjamin semua anggota kelompok secara individu mempelajari bahan yang ditugaskan tersebut.

2) Personal responsibility (tanggung jawab perseorangan). Pertanggungjawaban ini muncul jika dilakukan pengukuran terhadap keberhasilan kelompok. Tujuan pembelajaran kooperatif adalah membentuk semua anggota kelompok menjadi pribadi yang kuat. Tanggungjawab perseorangan adalah kunci untuk menjamin semua anggota yang diperkuat oleh kegiatan belajar bersama. Artinya, setelah mengikuti kelompok belajar bersama, anggota kelompok harus dapat menyelesaikan tugas yang sama.

3) Face to face promotive interaction (interaksi promotif). Unsur ini penting karena dapat menghasilkan saling ketergantungan positif. Ciri-ciri interaksi promotif adalah saling membantu secara efektif danefisien, saling memberikan informasi dan sarana yang diperlukan, memproses informasi bersama secara lebih efektif dan efisien, saling mengingatkan, saling membantu dalam merumuskan dan mengembangkan argumentasi serta meningkatkan kemampuan wawasan terhadap masalah yang dihadapi, saling percaya, dan saling memotivasi untuk memperoleh keberhasilan bersama.

4) Interpersonal skill (komunikasi antaranggota)Untuk mengkoordinasikan kegiatan siswa dalam pencapaian tujuan siswa harus adalah saling mengenal dan mempercayai, mampu berkomunikasi secara akurat dan tidak ambisius, saling menerima dan saling mendukung, serta mampu menyelesaikan konflik secara konstruktif.

5) Group processing (pemrosesan kelompok). Melalui pemrosesan kelompok dapat diidentifikasi dari urutan atau tahapan kegiatan kelompok dan kegiatan dari anggota kelompok. Siapa di antara anggota kelompok yang sangat 
membantu dan siapa yang tidak membantu. Tujuan pemrosesan kelompok adalah meningkatkan efektivitas anggota dalam memberikan kontribusi terhadap kegiatan kolaboratif untuk mencapai tujuan kelompok. Ada dua tingkat pemrosesan yaitu kelompok kecil dan kelas secara keseluruhan.

\subsection{Penelitian yang Relevan}

Penelitian Namirah (2018) berjudul Implementasi Model Cooperative Learning Tipe Student Teams Achievement Division (Stad) Pada Mata Pelajaran Perbankan Dasar Untuk Meningkatkan Keaktifan Belajar Siswa Kelas X Akuntansi 1 SMK Muhammadiyah 2 Klaten, menunjukkan bahwa model pembelajaran cooperative learning tipe Student Teams Achievement Division (STAD) mampu meningkatkan keaktifan belajar siswa. Khususnya pada siswa SMK Muhammadiyah 2 Klaten. Hazhira Qudsy et al., (2010) menemukan tidak ada perbedaan prestasi belajar Bahasa Indonesia pada siswa antara kelompok siswa yang diberikan pembelajaran kooperatif dengan kelompok siswa yang diberikan pembelajaran tradisional. Nurrizki (2016) menyimpulkan bahwa model pembelajaran kooperatif type jigsaw dapat meningkatkan hasil belajar siswa pada pembelajaran IPS di SDN Cimincrang Kota Bandung.

\subsection{Kerangka Berfikir}

Dalam setiap proses pembelajaran, terdapat mahasiswa yang memenuhi standar kriteria yang diinginkan, namun ada pula ada mahasiswa yang belum mampu mencapai standar minimal pencapaian tujuan yang ditetapkan oleh dosen. Dari hasil pengamatan, yang dilakukan di Progdi PPKn FKIP Unisri, ditemukan adanya mahasiswa yang tampak segan belajar, terutama pada mata kuliah Kapita Selekta Pendidikan. Hal ini ditunjukkan dari kurangnya perhatian mahasiswa dalam mengikuti perkuliahan mata kuliah Kapita Selekta Pendidikan, rendahnya keingintahuan mahasiswa terhadap mata kuliah Kapita Selekta Pendidikan. Hal ini menunjukkan rendahnya motivasi belajar mahasiswa dalam mata kuliah Kapita Selekta Pendidikan. Kondisi ini terjadi karena model pembelajaran yang diterapkan oleh dosen masih bersifat konvensional, yakni masih bertumpu pada dosen, mahasiswa kurang aktif di dilibatkan dalam proses pembelajaran. Untuk mengatasi kondisi tersebut, perlu penerapan model pembelajaran yang berorientasi pada keaktifan belajar mahasiswa. Model pembelajaran yang dirasakan efektif untuk mengatasi kondisi tersebut adalah model pembelajaran cooperative learning. Oleh karena itu, melalui model pembelajaran cooperative learning diharapkan dapat meningkatkan motivasi belajar mahasiswa khususnya pada Mata Kuliah Kapita Selekta Pendidikan Pada Program Studi PPKn

\section{METODE PENELITIAN}

\subsection{Jenis Penelitian}

Penelitian ini merupakan Penelitian Tindakan Kelas (PTK) yang dapat disebut juga penelitian pengembangan. Penelitian dilaksanakan dalam 2 siklus, dengan menerapkan metode-metode dalam pembelajaran kooperatif 


\subsection{Prosedur Penelitian}

Penelitian ini menggunakan pendekatan proses yang berkesinambungan yang direncanakan dalam 2 siklus. Dalam setiap siklusnya, meliputi empat tahap yaitu tahap perencanaan, pelaksanaan, observasi dan tahap refleksi.

\section{Tahap Perencanaan}

Kegiatan pada tahap ini meliputi: (1)Penyusunan SAP (Satuan AcaraPerkuliahan) yang melaksanakan metode pembelajaran kooperatif STAD pada mata kuliah Kapita Selekta Pendidikan yang berisikantentang: kompetensi standar, kompetensidasar, indikator, materi pokok, dan submateri pokok; (2) Penyusunan LKM (Lembar Kerja Mahasiswa); (3) Menyusun soal baik pretest dan post test; serta (4) Menyiapkan lembar observasi aktivitas mahasiswa secara individu, lembar observasi kelompok, serta LOKMP (Lembar Observasi Keterlaksanaan Model Pembelajaran)

\section{Tahap Pelaksanaan}

Kegiatan pada tahap ini meliputi: (1) Pemberian pretest untuk mengetahui kemampuan awal mahasiswa; (2) Dosen memberikan penjelasan mengenai materi Mata Kuliah Kapita Selekta Pendidikan sesuai dengan SAP; (3) Dosen memberikan tugas kelompok untuk didiskusikan dan membagi mahasiswa menjadi 4 kelompok yang terdiri dari 4 orang dalam tiap kelompok; (4) Dosen membimbing jalannya diskusi kelompok; (5) Dosen menutup kegiatan pembelajaran serta memberi motivasi pada mahasiswa.

\section{Observasi}

Pada tahap ini dilaksanakan proses observasi, terhadap pelaksanaan tindakan dengan menggunakan lembar observasi yang telah dibuat.

\section{Refleksi}

Hasil yang diperoleh pada tahap observasi dikumpulkan dan dianalisis. Hasil analisis digunakan untuk merefleksi diri, apakah langkah-langkah pembelajaran yang dilakukan sesuai dengan rencana yang sudah ditentukan. Disamping itu peneliti menganalisis hasil lembar observasi, dan mendiskusikan dampak pelaksanaan pembelajaran pada motivasi belajar mahasiswa.

\subsection{Tempat dan Waktu Penelitian}

Penelitian ini dilakukan di Jurusan PPKn Fakultas Keguruan dan Ilmu Pendidikan Universitas Slamet Riyadi Surakarta. Kegiatan penelitian ini meliputi persiapan eksperimen dan pelaksanaan eksperimen. Persiapan eksperimen mencakup persiapan materi, yakni memilih dan menetapkan topik yang akan diajukan. Selain persiapan materi, juga persiapan teknis, jadwal dan ruang eksperimen. Selanjutnya untuk pelaksanaan eksperimen dilakukan pembelajaran dengan metode cooperative learning. Penelitian ini dilakukan pada mahasiswa semester IV Jurusan PIPS Progdi PPKn Tahun Akademik 2018/2019. 


\subsection{Subjek Penelitian}

Subyek penelitian ini adalah mahasiswa semester IV Program Studi PPKn FKIP Unisri Surakarta Tahun Akademik 2018/2019 yang berjumlah 16 orang

\subsection{Teknik Pengumpulan Data}

Instrumen yang digunakan untuk pengumpulan data meliputi; (1) Lembar observasi aktivitas mahasiswa; efektivitas kelompok, serta keterlaksanaan pembelajaran; (2) Angket motivasi untuk mengetahui sejauh mana pembelajaran mampu meningkatkan motivasi belajar mahasiswa, dilihat dari persepsi mahasiswa dengan aspek yang dikaji minat belajar serta kenyamanan dan kepuasan mahasiswa dalampembelajaranserta (3) Evaluasi hasil belajar aspek kognitif yang mengacu pada materi yang telah dipelajari.

Ada 2 teknik pengumpulan data yang digunakan, yaitu teknik observasi dan teknik ujian. Teknik observasi digunakan untuk mengungkap aktivitas, efektivitas kelompok dan motivasi mahasiswa.

\subsection{Teknik Analisis Data}

Teknik analisis data menggunakan teknik deskriptif kualitatif dengan data yang diperolah dengan tujuan mengetahui tanggapan mahasiswa terhadap kegiatan pembelajaran, mengetahui aktivitas mahasiswa dalam proses pembelajaran serta mengetahui motivasi belajar mahasiswa dalam kegiatan pembelajaran. Untuk mengetahui tingkat keberhasilan mahasiswa setelah proses belajar mengajar, pada setiap siklusnya dilakukan tes evaluasi berupa tes tertulis.

\section{HASIL DAN PEMBAHASAN}

Hasil tindakan siklus I pada pembelajaran Kapita Selekta Pendidikan dengan metode STAD disajikan pada tabel 1 sampai tabel 4. Hasil megenai motivasi belajar mahasiswa dapat dilihat pada Tabel 5 .

Tabel 1. Hasil PreTest Kemampuan Awal Mahasiswa

\begin{tabular}{ccccc}
\hline No. & Skor & $\begin{array}{c}\text { Kategori } \\
\text { Ketuntasan }\end{array}$ & Frekuensi & $\begin{array}{c}\text { Presentase } \\
(\%)\end{array}$ \\
\hline 1 & $>75$ & Tuntas & 7 & 43,75 \\
2 & $<75$ & Tidak & 9 & 56,25 \\
& \multicolumn{5}{c}{ Tuntas } & 16 & 100 \\
\hline \multicolumn{5}{c}{ Jumlah }
\end{tabular}


Tabel 2. Hasil Observasi Aktivitas Mahasiswa pada Siklus I

\begin{tabular}{lccc}
\hline No & Aspek Penilaian & $\begin{array}{c}\text { Rerata Skor } \\
\text { Mahasiswa }\end{array}$ & Kriteria \\
\hline 1 & Visual activities & 2,9 & Kurang \\
2 & Oral activities & 3,3 & Cukup \\
3 & Listening activities & 3,0 & Cukup \\
4 & Writing activities & 3,0 & Cukup \\
5 & Emotional activities & 2,8 & Kurang \\
\hline & Total & 15,0 & Cukup \\
\hline
\end{tabular}

Tabel 3. Hasil Observasi Efektivitas Kelompok Siklus I

\begin{tabular}{cccc}
\hline No & Aspek penilaian & RerataSkor & Kriteria \\
\hline 1 & $\begin{array}{c}\text { Efisiensi pemecahan } \\
\text { masalah }\end{array}$ & 3,3 & Cukup \\
2 & Partisipasi anggota & 3,3 & Cukup \\
\hline \multicolumn{2}{c}{ Total } & 6,6 & Cukup \\
\hline
\end{tabular}

Tabel 4. Hasil Observasi Keterlaksanaan Pembelajaran Siklus I

\begin{tabular}{cccc}
\hline No & $\begin{array}{c}\text { Aspek } \\
\text { Pembelajaran }\end{array}$ & $\begin{array}{c}\text { Rerata } \\
\text { Skor }\end{array}$ & Kriteria \\
\hline 1 & Pendahuluan & 3,3 & Cukup \\
2 & Kegiatan Inti & 3,0 & Cukup \\
3 & Penutup & 3,7 & Cukup \\
\hline & Total & 10,0 & Cukup \\
\hline
\end{tabular}

Tabel 5. Hasil Analisis Motivasi Belajar Siklus I

\begin{tabular}{clcc}
\hline $\begin{array}{c}\text { Skala } \\
\text { Motivasi }\end{array}$ & \multicolumn{1}{c}{ Kategori } & Frekuensi & Presentase (\%) \\
\hline $85-100$ & Sangat Tinggi & 4 & 25 \\
$70-84$ & Tinggi & 9 & 56,25 \\
$55-69$ & Sedang & 3 & 18,75 \\
$40-54$ & Rendah & 0 & 0 \\
$0-39$ & Sangat Randah & 0 & 0 \\
\hline \multicolumn{2}{c}{ Jumlah } & 16 & 100 \\
\hline
\end{tabular}


Tabel 6. Hasil Evaluasi Pembelajaran Pada Siklus I

\begin{tabular}{|c|c|c|c|c|}
\hline No. & Skor & $\begin{array}{c}\text { Kategori } \\
\text { Ketuntasan }\end{array}$ & Frekuensi & Presentase $(\%)$ \\
\hline 1 & $>75$ & Tuntas & 12 & 75 \\
\hline 2 & $<75$ & Tidak Tuntas & 4 & 25 \\
\hline \multicolumn{3}{|c|}{ Jumlah } & 16 & 100 \\
\hline
\end{tabular}

Setelah dilaksanakan proses pembelajaran dengan menerapkan Model Pembelajaran Kooperatif Tipe STAD pada siklus I, maka langkah yang selanjutnya harus dilakukan adalah refleksi. Secara keseluruhan Penerapan Model Pembelajaran Kooperatif Tipe STAD pada siklus I berjalan cukup lancar dan sesuai dengan prosedur ataupun kerangka yang telah disusun sebelumnya. Proses pembelajaran yang dilaksanakan dosen sudah cukup baik, walaupun ada beberapa tahap pembelajaran yang dilaksanakan belum optimal seperti pengelolaan kelas dikarenakan mahasiswa belum terbiasa melakukan pembelajaran dengan Model Pembelajaran Kooperatif Tipe STA, sehingga capaian belajar mahasiswa pada siklus I belum optimal. Berdasarkan penelitian siklus I, beberapa hal perlu dijadikan pedoman untuk perbaikan pelaksanaan siklus II. Diharapkan siklus II berjalan lebih baik dan dapat mencapai target keberhasilan.

Berdasarkan hasil dari tindakan siklus II pada pembelajaran Kapita Selekta Pendidikan dengan motede STAD diperoleh hasil sebagai berikut: Tabel 7 . menunjukkan hasil pretest untuk mengetahui kemampuan awal mahasiswa, Tabel 8. merupakan hasil observasi aktivitasmahasiswa. Hasil observasi efektivitas kelompok disajikan pada Tabel 9; Tabel 10. menyajikan ringkasan data keterlaksanaanpembelajaran. Hasil terhadap motivasi belajar mahasiswa dapat dilihat pada Tabel 11 .

Tabel 7. Hasil PreTest Kemampuan Awal Mahasiswa

\begin{tabular}{|c|c|c|c|c|}
\hline No. & Skor & Kategori Ketuntasan & Frekuensi & Presentase (\%) \\
\hline 1 & $>75$ & Tuntas & 13 & 81,25 \\
\hline 2 & $<75$ & Tidak Tuntas & 3 & 19,75 \\
\hline \multicolumn{3}{|r|}{ Jumlah } & 16 & 100 \\
\hline
\end{tabular}

Tabel 8. Hasil Observasi Aktivitas Mahasiswa pada Siklus II

\begin{tabular}{llcc}
\hline No & Aspek Penilaian & Rerata & Kriteria \\
\hline 1 & Visual activities & 4,1 & Baik \\
2 & Oral activities & 4,1 & Baik \\
3 & Listening activities & 3,8 & Baik \\
4 & Writing activities & 4,3 & Baik \\
5 & Emotional activities & 4,1 & Baik \\
\hline & Total & 20,4 & Baik \\
\hline
\end{tabular}


Tabel 9. Hasil Observasi Efektivitas Kelompok Siklus II

\begin{tabular}{cccc}
\hline No & Aspek penilaian & Rerata & Kriteria \\
\hline 1 & Efisiensi pemecahan masalah & 4,0 & Baik \\
2 & Partisipasi anggota & 4,5 & Baik \\
\hline & Total & 8,5 & Baik \\
\hline
\end{tabular}

Tabel 10. Hasil Observasi Keterlaksanaan Pembelajaran Siklus II

\begin{tabular}{cccc}
\hline No & Aspek Pembelajaran & Rerata & Kriteria \\
\hline 1 & Pendahuluan & 3,7 & Cukup \\
2 & Kegiatan Inti & 4,7 & Baik \\
3 & Penutup & 4,3 & Baik \\
\hline & Total & 12,7 & Baik \\
\hline
\end{tabular}

Tabel 11. Hasil Analisis Motivasi Belajar Siklus II

\begin{tabular}{|c|c|c|c|}
\hline Skala Motivasi & Kategori & Frekuensi & Presentase (\%) \\
\hline $85-100$ & Sangat Tinggi & 5 & 31,25 \\
\hline $70-84$ & Tinggi & 10 & 62,50 \\
\hline $55-69$ & Sedang & 1 & 6,25 \\
\hline $40-54$ & Rendah & 0 & 0 \\
\hline $0-39$ & Sangat Randah & 0 & 0 \\
\hline \multicolumn{2}{|c|}{ Jumlah } & 16 & 100 \\
\hline
\end{tabular}

Tabel 13. Hasil Evaluasi Pembelajaran Pada Siklus II

\begin{tabular}{ccccc}
\hline No. & Skor & Kategori Ketuntasan & Frekuensi & Presentase (\%) \\
\hline 1 & $>75$ & Tuntas & 16 & 100 \\
2 & $<75$ & Tidak Tuntas & 0 & 0 \\
\hline \multicolumn{2}{r}{ Jumlah } & 16 & 100 \\
\hline
\end{tabular}

Berdasarkan hasil penelitian pada siklus II, dilakukan refleksi seperti pada siklus I. Refleksi ini dilakukan dengan mempertimbangkan capaian belajar mahasiswa yang diperoleh pada siklus II dan mengevaluasi hasil tindakan terhadap Penerapan Model Pembelajaran Kooperatif Tipe STAD. Proses pembelajaran Mata Kuliah Kapita Selekta Pendidikan dengan menerapkan Model Pembelajaran Kooperatif Tipe STAD pada siklus II menunjukkan hasil yang memuaskan dan memenuhi target yang sudah ditetapkan. Hal ini terbukti dari Hasil Evaluasi serta Motivasi Belajar yang dicapai mahasiswa menunjukkan adanya peningkatan. 


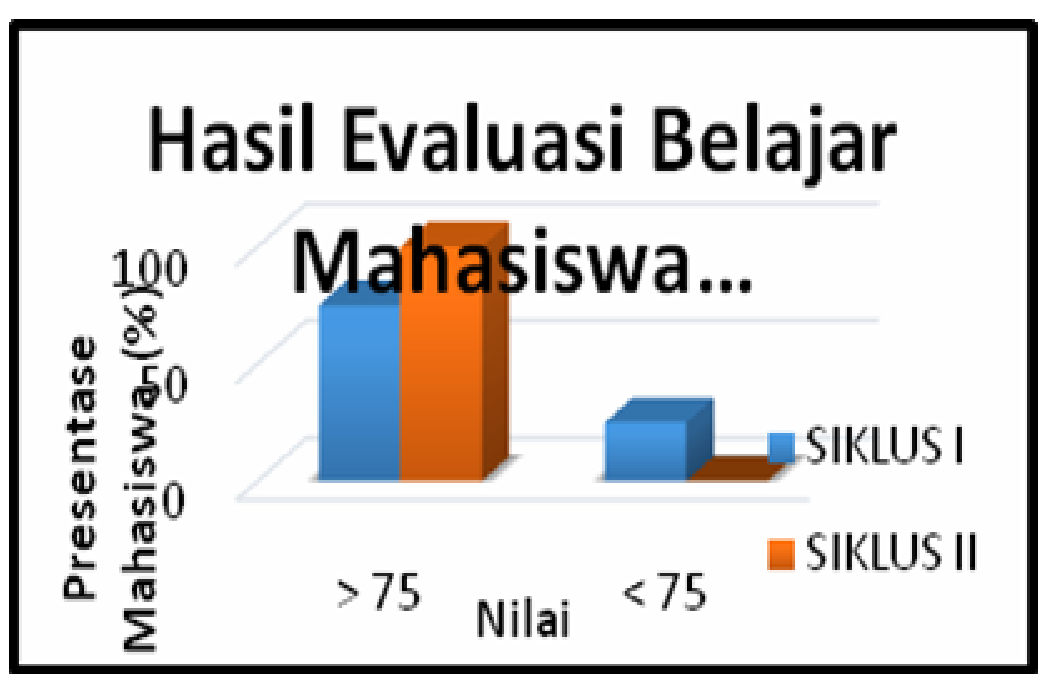

Gambar 2. Grafik Perbandingan Hasil Belajar Mahasiswa

Pada Siklus I dan Siklus II Berdasarkan grafik di atas dapat dilihat bahwa terjadi peningkatan hasil evaluasi belajar mahasiswa dengan menerapkan Model Pembelajaran Kooperatif Tipe STAD. Pada Siklus I sebanyak 25\% mahasiswa yang nilainya belum memenuhi batas nilai tuntas dan $75 \%$ mendapatkan nilai tuntas. Setelah diperbaiki proses pembelajaran pada Siklus II, hasil evaluasi belajar mahasiswa mengalami peningkatan menjadi $100 \%$ memperoleh nilai $\geq 75$. Hal tersebut menunjukan bahwa Model Pembelajaran Kooperatif Tipe STAD dapat meningkatkan hasil belajar mahasiswa khususnya pada Mata Kuliah Kapita Selekta Pendidikan.

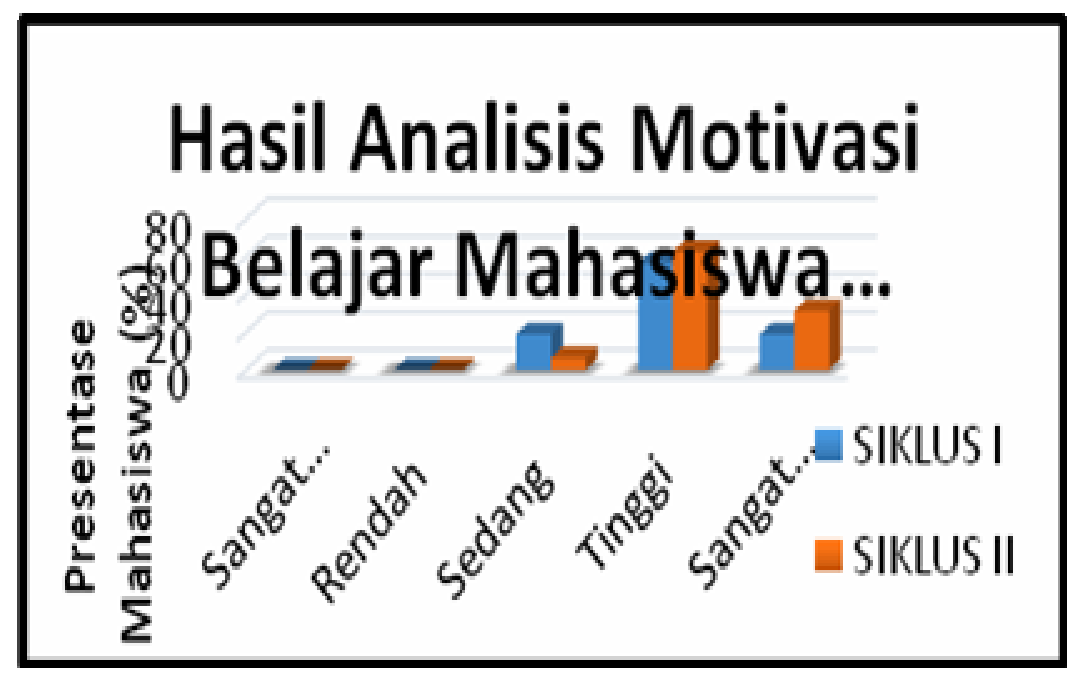

Gambar 3. Grafik Perbandingan Hasil Analisis Motivasi Belajar Mahasiswa Pada Siklus I dan Siklus II 
Berdasarkan grafik di atas, dapat dilihat pada Siklus I sebanyak 18,75\% mahasiswa memiliki motivasi belajar kategori sangat tinggi; sebanyak 56,25\% mahasiswa memiliki motivasi belajar tinggi; dan 25\% mahasiswa memiliki motivasi belajar kategori sedang. Setelah dilakukan proses pembelajaran apada Siklus II terlihat adanya peningkatan presentase motivasi belajar mahasiswa. Seperti yang dapat dilihat pada grafik, sebanyak $31,25 \%$ mahasiswa memiliki motivasi belajar kategori sangat tinggi; sebanyak 62,50\% mahasiswa memiliki motivasi belajar kategori tinggi; dan 6,25\% mahasiswa memiliki motivasi belajar kategori sedang. Berdasarkan hasil tersebut, dapat disimpulkan bahwa Model Pembelajaran Kooperatif Tipe STAD dapat meningkatkan motivasi belajar mahasiswa khususnya dalam Mata Kuliah Kapita Selekta Pendidikan

\section{SIMPULAN}

Berdasarkan pembahasan yang telah dilakukan pada bab sebelumnya secara umum dapat disimpulkan bahwa penerapan metode pembelajaran kooperatif tipe STAD dapat meningkatkan motivasi belajar mahasiswa pada Mata Kuliah Kapita Selekta Pendidikan. Adapun kesimpulan secara rinci sebagai berikut:

1. Secara keseluruhan, motivasi belajar mahasiswa rata-rata terdapat pada kategori tinggi baik Siklus I maupun Siklus II dengan presentase 56,25 dan $62,50 \%$

2. Dengan adanya peningkatan motivasi belajar mahasiswa secara signifikan juga berpengaruh terhadap hasil evaluasi belajar dengan kategori nilai tuntas lebih $\geq 75$.

\section{SARAN}

Adapun saran peneliti berdasarkan kesimpulan dalam penelitian ini adalah diharapkan dapat mempelajari pedoman pelaksanaan pembelajaran kooperatif dan berlatih melaksanakannya dalam kelas. Melalui pelaksanaan pembelajaran kooperatif dengan baik, mahasiswa akan lebih berhasil dalam menguasai materi kuliah sehingga mahasiswa termotivasi dalam mengikuti kegiatan pembelajaran dan aktif dalam tugas yang diberikan oleh dosen.

\section{DAFTAR PUSTAKA}

A'la, Miftahul. 2011. Quantum Teaching. Diva Press: Jakarta

A.M. Sardiman, 2007. Interaksi dan Motivasi Belajar Mengajar. Bandung, Rajawali Pers

Arends, R. 2008. Learning To Teach - Belajar untuk Mengajar. Yogyakarta : Pustaka Pelajar. 
Attle, S. \& Baker, B. 2007. Cooperative Learning In a Competitive EnvirontmentClassroom Application. International Journal of Learning and Learning in Higher Education. Volume 19, Number 1, 77-83 ISSN $1812-9129$

Dimyati dan Mudjiono. 2009. Belajar dan Pembelajaran. Jakarta: Rineka Cipta

Hamzah B. Uno. 2011. Teori Motivasi dan Pengukurannya: Analisis di Bidang Pendidikan. Jakarta: Bumi aksara

Hamalik, Oemar. 2011. Kurikulum dan Pembelajaran. Jakarta: Bumi Aksara Imron, Ali. 1996. Belajar dan Pembelajaran. Jakarta: Dunia Pustaka Jaya Jakarta Jatmiko, RD. 2004. Manajemen Strategi. Yogyakarta: BPFE

Gunarsa, Singgih. 1990. Dasar dan Teori Perkembangan Anak. Jakarta: PT BPK Gunung Mulia

Ibrahim, M. 2000. Pembelajaran Kooperatif. Surabaya: University Press.

Naimah, Unun. 2018. Implementasi Model Cooperative Learning Tipe Student Teams Achievement Division (Stad) Pada Mata Pelajaran Perbankan Dasar Untuk Meningkatkan Keaktifan Belajar Siswa Kelas X Akuntansi 1 Skm Muhammadiyah 2 Klaten Utara Tahun Ajaran 2017/ 2018. Program Studi Pendidikan Akuntansi Fakultas Keguruan Dan Ilmu Pendidikan Universitas Muhammadiyah Surakarta 2018

Nurrizki, Yuliana. 2016. PENERAPAN MODEL PEMBELAJARAN COOPERATIVE LEARNING TIPE JIGSAW UNTUK MENINGKATKAN HASIL BELAJAR SISWA PADA PEMBELAJARAN ILMU PENGETAHUAN SOSIAL (Penelitian Tindakan Kelas Pada Materi Masal.

Qudsy, Hazhira, dkk. 2011. Pengaruh Metode Pembelajaran Kooperatif (Cooperative Learning) Dan Motivasi Belajar Terhadap Prestasi Belajar Siswa SMA. Proyeksi, Vol. 6 (2) 2011, 34-49

Rakhmat, Jalaludin. 1991. Psikologi Komunikasi. Remaja Rosdakarya. Bandung Soekamto, Toeti. 1992. Strategi Belajar Mengajar. BP-FKIP UMS

Sugandi, Ahmad. 2000. Teori Pembelajaran. Semarang: UPT MKK UNNES

Supriyono, Agus. 2009. Cooperative Learning, Teori \& Aplikasi PAIKEM. Surabaya: Pustaka Pelajar

Suryabrata, Sumadi, 2011. Psikologi Pendidikan. Jakarta: PT. Raja Grafindo Persada

Te-Yi Chan, Rou-Mei Wang, Bin-Shyan Jong, Yen-The Hsia \& Tsong-Wuu Lin. 2008. Conceptual Graph Based Learning Material. Producing Strategy For Cooperative Learning. ASEE/IEEE Frontiers in Education Conference. 38th. $978-1-4244-1970$ - 8/08. October 22 - 25, 2008, Saratoga Springs, New York

Winkel, W. S. 2004. Psikologi Pendidikan dan Evaluasi Belajar. Jakarta: PT. Gramedia Pustaka Utama

Zakaria, E., Iksan, Z. 2007. Promoting Cooperative Learning in Science and Mathematics, Education: A Malaysian Perspective. Eurasia Journal of Education. 